[Note]

\title{
Characterization of $\mathrm{CoMo}-\mathrm{Al}_{2} \mathrm{O}_{3}$ Catalyst by Combination Technique of Temperature-programmed Sulfiding and Electron Spin Resonance (TPS-ESR)
}

\author{
Eiji HayashI $^{\dagger 1) *}$, Eiji Iwamatsu ${ }^{\dagger 1}$, Shakeel AHMED ${ }^{\dagger 1}$, Augustine K.K. LeE ${ }^{\dagger 1}$, Halim Hamid ${ }^{\dagger 1}$, \\ Yuzo SANADA ${ }^{\dagger 1}$, and Toshikazu YonedA ${ }^{\dagger 2}$ \\ †1) Research Institute, King Fahd University of Petroleum and Minerals, Dhahran 31261, Saudi Arabia \\ †2) Advanced Catalysts Research Laboratory, Petroleum Energy Center, Kawasaki 213-0012
}

(Received August 4, 1997)

\begin{abstract}
$\mathrm{CoMo}-\mathrm{Al}_{2} \mathrm{O}_{3}$ catalyst was characterized with a combination technique of temperature-programmed sulfiding (TPS) and electron spin resonance (ESR). The behavior of the $\mathrm{MoO}_{3}$ loaded over the surface of $\mathrm{Al}_{2} \mathrm{O}_{3}$ obtained from TPS has been compared with that of $\mathrm{Mo}^{5+}$ observed with ESR at isothermal and elevated temperatures. The $\mathrm{Mo}^{6+}$ in the $\mathrm{MoO}_{3}$ supported is easily reduced with $\mathrm{H}_{2} \mathrm{~S}+\mathrm{H}_{2}$ under very mild conditions and transformed into $\mathrm{Mo}^{5+}$ as an intermediate. This $\mathrm{Mo}^{5+}$ peak drastically decreased around $200^{\circ} \mathrm{C}$ with $\mathrm{H}_{2} \mathrm{~S}$ desorption, and $\mathrm{H}_{2}$ consumption appeared simultaneously in the TPS profile. These results suggest that the $\mathrm{Mo}^{5+}$ species observed with ESR associates with sulfur from $\mathrm{H}_{2} \mathrm{~S}$.
\end{abstract}

\section{Introduction}

$\mathrm{CoMo}-\mathrm{Al}_{2} \mathrm{O}_{3}$ has been used as a hydrotreating catalyst for petroleum fractions because of its high activities for hydrodesulfurization (HDS) and hydrogenation. In most cases, the catalyst in the active state has a metal sulfide structure because of the treatment with hydrogen and sulfur-containing compounds before reaction. The correlation between reaction activity and the sulfiding behavior provides fundamental information for HDS and hydrocracking catalyst characterization.

The temperature-programmed sulfiding (TPS) method has been developed to investigate the sulfiding behavior of the HDS catalyst and it has been recognized as a useful technique for catalyst characterization $^{1-5)}$. Although the sulfiding process of the catalyst can be observed with this method, still some uncertainty remains about the sulfiding mechanism. Moreover, but slight attention has been paid to the phenomena of TPS at low sulfiding temperatures.

The ESR has also been recognized as a useful catalyst-characterization technique. A large number of ESR studies of Mo species in HDS catalysts have been carried out $\left.{ }^{6)} \sim 11\right)$, because Mo is one of the typical loading metals for HDS catalysts, and Mo provides ESR active species as $\mathrm{Mo}^{5+}$ from/to the ESR inactive species (for example $\mathrm{Mo}^{6+}$ or $\mathrm{Mo}^{4+}$ ) after sulfiding. In

* To whom correspondence should be addressed. (Present address) Center for Advanced Research of Energy Technology, Hokkaido University, North 13, West 8, Sapporo 060-8628 this report, the ESR method is employed together with TPS in order to gain deep insight into the sulfiding behavior of the catalyst.

\section{Experimental}

\section{1. Preparation of $\mathrm{CoMo}-\mathrm{Al}_{2} \mathrm{O}_{3}$}

$\mathrm{CoMo}-\mathrm{Al}_{2} \mathrm{O}_{3}$ was prepared by impregnation technique. A mixture of aqueous solutions of ammonium heptamolybdate and cobalt nitrate was impregnated into the powder of $\gamma-\mathrm{Al}_{2} \mathrm{O}_{3}$. The amounts of the metals loaded were $15 \mathrm{wt} \%$ Mo as $\mathrm{MoO}_{3}$ and $4 \mathrm{wt} \% \mathrm{Co}$ as $\mathrm{CoO}$. The resulting sample was dried at $120^{\circ} \mathrm{C}$ overnight before it was finally calcined at $400^{\circ} \mathrm{C}$ overnight in air.

\section{2. Measurement of TPS}

Temperature-programmed sulfiding (TPS) experiments were carried out with the TPS equipment (Model TP-2000) supplied by Ohkura Riken Co., Ltd., Japan. Prior to TPS measurements, the catalyst $(0.15 \mathrm{~g})$ was heated in the TPS reactor at $400^{\circ} \mathrm{C}$ for $2 \mathrm{~h}$ in a stream of dry air $(30 \mathrm{ml} / \mathrm{min})$ through a moisture trap. After the catalyst was cooled to room temperature, air was replaced and purged with argon (flow rate: $30 \mathrm{ml} / \mathrm{min}$ ). Sulfiding gas $\left(\mathrm{H}_{2} \mathrm{~S}: \mathrm{H}_{2}: \mathrm{Ar}=2: 42: 56\right)$ (flow rate: 18 $\mathrm{m} l / \mathrm{min}$ ) was then introduced to start TPS. The catalyst was heated up to $1030^{\circ} \mathrm{C}$ with a temperature raising rate of $10^{\circ} \mathrm{C} / \mathrm{min}$. Effluents from the reactor were monitored by TCD and UV detectors.

\section{3. Combination of TPS and ESR}

Prior to performing the ESR measurements, the pro- 


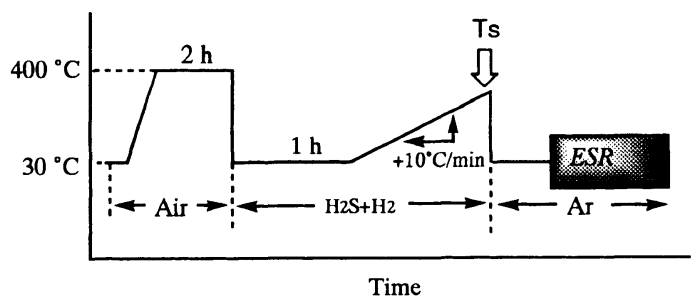

Scheme 1 Temperature-programmed Sulfiding Condition of Catalyst for ESR

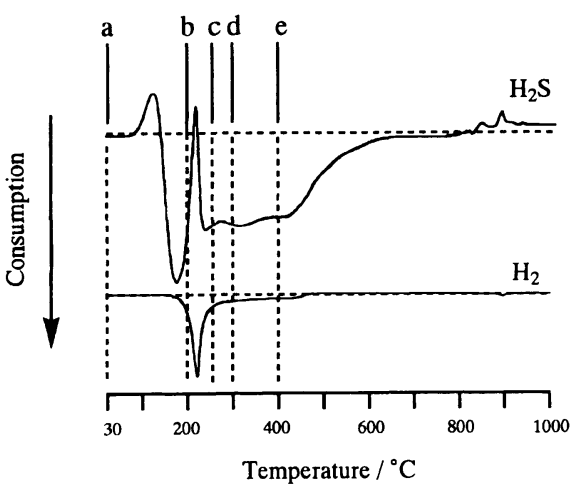

Fig. 1 TPS Profile of CoMo- $\mathrm{Al}_{2} \mathrm{O}_{3}$ Catalyst

file of TPS was obtained by the method described in 2. 2. The catalyst sample was installed in a quartz reactor, which was used as TPS reactor and as in-situ ESR sample tube without exposure to air, and the ESR signal was obtained.

The ESR measurements were carried out using a JEOL RE1X spectrometer, which was operated in the $\mathrm{X}$-band microwave frequency. For the determination of $g$-value, DPPH was used as a standard material. The ESR spectra of the catalysts in the reactor were obtained under Ar atmosphere at room temperature by step(a) and by step(b).

(a) Temperature-programmed sulfiding - ESR: The catalyst sample exposed and sulfided in a $\mathrm{H}_{2}-\mathrm{H}_{2} \mathrm{~S}-\mathrm{Ar}$ mixture at various temperatures in the range from room temperature to $600^{\circ} \mathrm{C}$ was brought to the ESR cavity and $\mathrm{Mo}^{5+}$ signal was measured. This procedure is summarized in Scheme 1.

(b) Isothermal sulfiding - ESR: The catalyst sample for characterization with ESR was carried out by isothermal sulfiding at $30^{\circ} \mathrm{C}$ for a time from 10 to $60 \mathrm{~min}$. This procedure is summarized in Scheme 2.

\section{Results and Discussion}

\section{1. TPS of CoMo- $\mathrm{Al}_{2} \mathrm{O}_{3}$ Catalyst}

Figure 1 shows the TPS profile of the $\mathrm{CoMo}-\mathrm{Al}_{2} \mathrm{O}_{3}$ catalyst, which clearly shows consumption and desorp- tion peaks of $\mathrm{H}_{2} \mathrm{~S}$ and $\mathrm{H}_{2}$. Moreover, the profile is almost similar to that observed by Moulijn et $a .^{2)}$. The first desorption of $\mathrm{H}_{2} \mathrm{~S}$, adsorbed physically on the catalyst, was recognized at $120^{\circ} \mathrm{C}$. After this desorption, $\mathrm{H}_{2} \mathrm{~S}$ was consumed at temperatures up to $200^{\circ} \mathrm{C}$. A marked consumption of $\mathrm{H}_{2}$ occurred in a relatively sharp peak at around $220^{\circ} \mathrm{C}$ while $\mathrm{H}_{2} \mathrm{~S}$ was simultaneously released. The sulfiding mechanism from the evidence above in the low-temperature region has been explained as follows ${ }^{2}$. The dominant reaction at lowtemperature stage occurs with the exchange between $\mathrm{O}$ and $\mathrm{S}$ on $\mathrm{Mo}^{6+}$ ions. Subsequently, the reduction of $\mathrm{Mo}^{6+}$ takes place by the rupture of the Mo-S bonds, together with the formation of elemental sulfur. This sulfur is catalytically reduced to $\mathrm{H}_{2} \mathrm{~S}$ at $c a .230^{\circ} \mathrm{C}$. Therefore, $\mathrm{H}_{2} \mathrm{~S}$ predominates during low-temperature sulfiding, while $\mathrm{H}_{2}$ plays as a reductant of elemental sulfur. According to their sulfiding mechanism, no direct evidence of elemental sulfur formation is given, although monitoring for $\mathrm{H}_{2} \mathrm{O}$ formation has been carried out, that is, the TPS method cannot detect the reduction of $\mathrm{Mo}^{6+}$ followed by the formation of elemental sulfur because the resultant sulfur will be strongly adsorbed to the support. This implies that elemental sulfur formation does not consequently change the gas composition.

\section{2. ESR of Sulfurized $\mathrm{CoMo}-\mathrm{Al}_{2} \mathrm{O}_{3}$ Catalyst}

It is easily concluded from the evidence that $\mathrm{Mo}^{6+}$ alters the lower valence species such as $\mathrm{Mo}^{5+}, \mathrm{Mo}^{4+}$, and so on, during the $\mathrm{H}_{2} \mathrm{~S}+\mathrm{H}_{2}$ treatment. Therefore, the detection of $\mathrm{Mo}^{5+}$ by ESR is useful at various sulfiding temperatures because $\mathrm{Mo}^{5+}$ is ESR active species, while $\mathrm{Mo}^{6+}$ and $\mathrm{Mo}^{4+}$ are ESR inactive species. ESR spectra of CoMo- $\mathrm{Al}_{2} \mathrm{O}_{3}$ catalyst are shown in Fig. 2. The ESR measurements were carried out in argon atmosphere for the pretreated catalyst, followed by Scheme 1. ESR signals with the $g$-value of 1.96 were assigned as $\mathrm{Mo}^{5+12), 13)}$. Sulfiding of $\mathrm{CoMo}-\mathrm{Al}_{2} \mathrm{O}_{3}$ at room temperature gave a strong $\mathrm{Mo}^{5+} \mathrm{ESR}$ spectrum as seen in Fig. 2a. The low-temperature sulfiding mechanism of $\mathrm{MoO}_{3}$ proposed by Moulijn et al. ${ }^{2)}$ did not suggested the formation of $\mathrm{Mo}^{5+}$, but the formation of substantial amounts of $\mathrm{Mo}^{5+}$ was observed in X-Ray Photoelectron Spectroscopy (XPS) ${ }^{14)}$ and ESR ${ }^{6)}$ studies. The intensity of the $\mathrm{Mo}^{5+}$ peak observed at $30^{\circ} \mathrm{C}(\mathrm{a}$ in Fig. 2) was almost the same as that observed at $200^{\circ} \mathrm{C}$ (b in Fig. 2). The intensity decreased considerably with increasing sulfiding temperature from 250 to $400^{\circ} \mathrm{C}$ (c-e in Fig. 2). Its possible explanation is that $\mathrm{Mo}^{5+}$ is further reduced to $\mathrm{Mo}^{4+}$, which has been assigned as $\mathrm{MoS}_{2}$ in this sulfiding temperature region ${ }^{2)}$.

\section{3. TPS-ESR of CoMo- $\mathrm{Al}_{2} \mathrm{O}_{3}$ Catalyst}

To elucidate the formation process of $\mathrm{Mo}^{5+}$ species during sulfiding, the $\mathrm{Mo}^{5+} \mathrm{ESR}$ peak intensity was monitored at $30^{\circ} \mathrm{C}$ as a function of exposure time (i.e., isothermal condition) and monitored also at elevating 


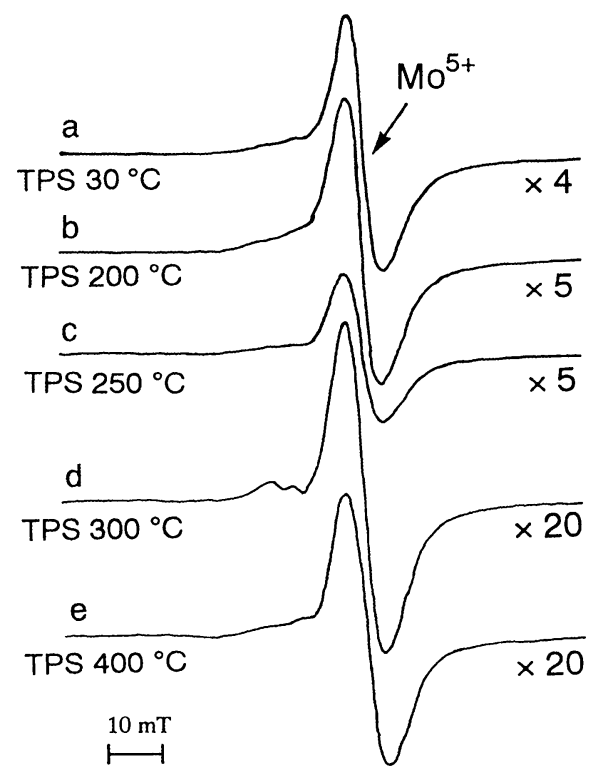

Temperature-programmed sulfiding temperature (TPS temp.) of a-e corresponds to those points in Fig. 1 .

Fig. $2 \mathrm{Mo}^{5+}$ ESR Spectra of $\mathrm{CoMo}-\mathrm{Al}_{2} \mathrm{O}_{3}$ Catalyst after Temperature-programmed Sulfiding at Various Temperatures

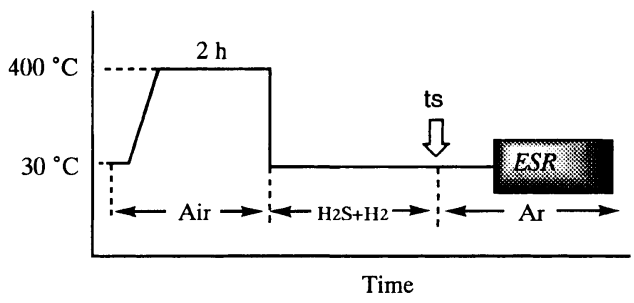

Scheme 2 Isothermal Sulfiding Condition of Catalyst for ESR

temperature by means of TPS technique. The results are shown in Fig. 3.

Isothermal sulfiding at $3^{\circ} \mathrm{C}$ : At the isothermal sulfiding stage, ESR spectra of $\mathrm{CoMo}-\mathrm{Al}_{2} \mathrm{O}_{3}$ were measured according to the treatment of Scheme 2. As shown in the TPS profile at the isothermal sulfiding stage in Fig. 3, the adsorption peak of $\mathrm{H}_{2} \mathrm{~S}$ appeared just after the introduction of the sulfiding gas. This adsorption was almost completed nearly within $20 \mathrm{~min}$. Although $\mathrm{H}_{2} \mathrm{~S}$ was adsorbed physically on the catalyst surface under this condition, some part of the adsorbed $\mathrm{H}_{2} \mathrm{~S}$ was consumed by sulfiding of $\mathrm{MoO}_{3}$ because the ESR intensity of $\mathrm{Mo}^{5+}$ drastically increased with the exposure time. The peak intensity was saturated within $60 \mathrm{~min}$. If this sulfiding is attributed to the $\mathrm{O}-\mathrm{S}$ exchange mechanism of $\mathrm{MoO}_{3}{ }^{2)}, \mathrm{H}_{2} \mathrm{O}$ must be produced on the catalyst ${ }^{2}$. Unfortunately, the production of $\mathrm{H}_{2} \mathrm{O}$ at low temperature sulfiding stages could not be confirmed by TPS method and by TPS-ESR method.
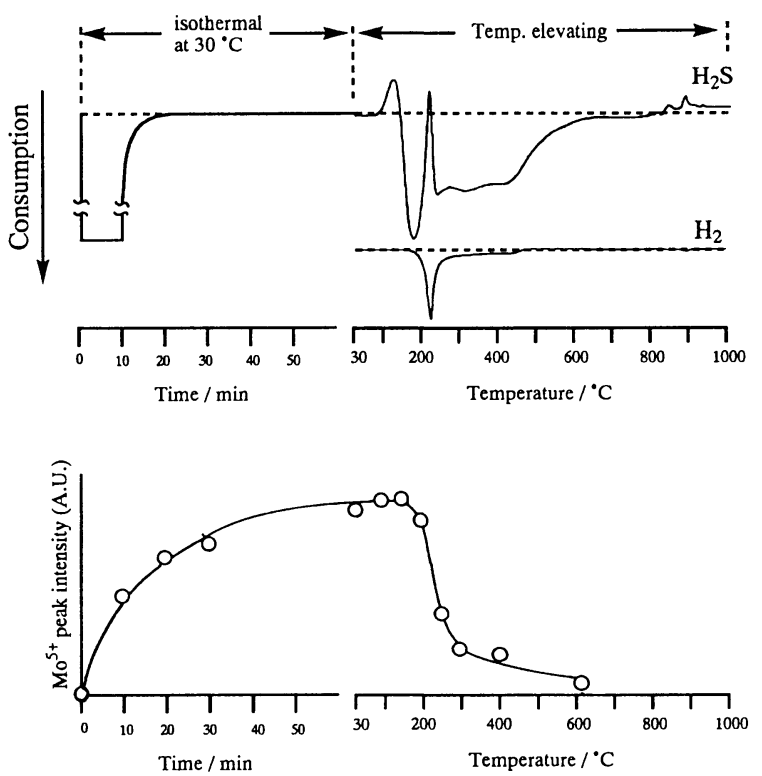

Fig. 3 TPS Profile and $\mathrm{Mo}^{5+}$ ESR Peak Intensity of CoMo$\mathrm{Al}_{2} \mathrm{O}_{3}$ Catalyst at Isothermal Sulfiding and Temperature-programmed Sulfiding Stage

Temperature-programmed sulfiding from 30 to $200^{\circ} \mathrm{C}$ : The $\mathrm{Mo}^{5+}$ peak intensity entirely was unchanged for this temperature region as shown in Fig. 3. On the other hand, $\mathrm{H}_{2} \mathrm{~S}$ was consumed without $\mathrm{H}_{2}$ consumption. This $\mathrm{H}_{2} \mathrm{~S}$ consumption at about $180^{\circ} \mathrm{C}$ has been successfully explained as $\mathrm{O}-\mathrm{S}$ exchange of $\mathrm{MoO}_{3}{ }^{2)}$. The $\mathrm{O}-\mathrm{S}$ exchange reaction of $\mathrm{MoO}_{3}$ over this temperature region is not associated with the formation and reduction of the $\mathrm{Mo}^{5+}$ species.

Temperature-programmed sulfiding from 200 to $600^{\circ} \mathrm{C}$ : In Fig. 3, a drastic decrease in the $\mathrm{Mo}^{5+}$ species was observed above $220^{\circ} \mathrm{C}$. In addition, $\mathrm{H}_{2} \mathrm{~S}$ desorption and $\mathrm{H}_{2}$ consumption peaks appeared simultaneously in the TPS profile. The $\mathrm{Mo}^{5+}$ ESR peak was observed just after the flow of sulfiding gas $\left(\mathrm{H}_{2} \mathrm{~S}+\mathrm{H}_{2}\right)$ at $30^{\circ} \mathrm{C}$ and decreased with the desorption of $\mathrm{H}_{2} \mathrm{~S}$ at about $220^{\circ} \mathrm{C}$. The reduction process of $\mathrm{Mo}^{6+}$ must take account of the following paths:

$$
\mathrm{Mo}^{6+} \rightarrow \mathrm{Mo}^{5+} \rightarrow \mathrm{Mo}^{4+} \rightarrow \rightarrow \mathrm{Mo}^{0}
$$

Therefore, our results suggest that (i) $\mathrm{Mo}^{5+}$ species observed with ESR are associated with the sulfur from $\mathrm{H}_{2} \mathrm{~S}$, (ii) $\mathrm{Mo}^{6+}$ species are reduced to $\mathrm{Mo}^{5+}$ species by $\mathrm{H}_{2} \mathrm{~S}$ producing $\mathrm{Mo}^{5+}-\mathrm{S}$ species, and (iii) $\mathrm{Mo}^{5+}-\mathrm{S}$ species are reduced to $\mathrm{Mo}^{4+}$ species by the release of sulfur. It has been explained that desorbed $\mathrm{H}_{2} \mathrm{~S}$ is produced with the reduction of elemental sulfur, which is formed by sulfiding of $\mathrm{MoO}_{3}$ at low-sulfiding temperatures ${ }^{2), 15)-17)}$. However, $\mathrm{H}_{2} \mathrm{~S}$ is produced not only from the reduction of isolated elemental sulfur but also from the reduction of the sulfur associated with the $\mathrm{Mo}^{5+}$ species. It seems that the $\mathrm{Mo}^{5+}-\mathrm{S}$ bond strength over the surface of $\mathrm{Al}_{2} \mathrm{O}_{3}$ may be very weak, and the sulfur 
associated with the $\mathrm{Mo}^{5+}$ species is easily reduced at the temperature required for elemental sulfur reduction. On the other hand, Muijsers et al. have studied different states of sulfur and molybdenum occurring during sulfidation by XPS, and they have observed the presence of disulfide ligands and substantial amounts of $\mathrm{Mo}^{5+}$ during an early stage of the sulfiding by XPS ${ }^{14}$. In their experiments, the $\mathrm{Mo}^{5+}$ species have been observed with $\mathrm{S}_{2}{ }^{2-}$ after sulfiding at low temperatures $\left(25-125^{\circ} \mathrm{C}\right)$, and both species have disappeared almost completely above $200-250^{\circ} \mathrm{C}$. Our results from the combination technique of TPS-ESR agree with those of the XPS studies of Muijsers et al.

It is well known that $\mathrm{Mo}^{5+}$ species observed with ESR are not necessarily the same as those observed by $\mathrm{XPS}^{18)-20)}$. This is one of the answers relevant to the site and role of the active species of the catalyst for given reactions such as hydrodesulfurization and hydrogenation. More concrete discussions on the results of this study will come about with further investigation.

\section{Conclusions}

The reduction mechanism of $\mathrm{MoO}_{3}$ in the sulfiding process of $\mathrm{CoMo}-\mathrm{Al}_{2} \mathrm{O}_{3}$ was studied with the combined system of TPS and TPS-ESR methods. The $\mathrm{Mo}^{5+}$ species, one of the resultant species of $\mathrm{Mo}^{6+}$ reduction, was produced during sulfiding at $30^{\circ} \mathrm{C}$ and suddenly reducing at $220^{\circ} \mathrm{C}$ and associating with $\mathrm{H}_{2} \mathrm{~S}$ desorption and $\mathrm{H}_{2}$ consumption. The $\mathrm{Mo}^{5+}$ is reduced to a Mo species with a lower valence like $\mathrm{Mo}^{4+}$ over a narrow temperature range in temperature-programmed sulfiding. These results obtained using the ESR technique could be one piece of evidence that the $\mathrm{Mo}^{5+}$ species associates with sulfur.

\section{Acknowledgments}

The experimental work was held at Research Institute, KFUPM. The study has been carried out as a joint research project of the Petroleum Energy Center with the subsidy of the Ministry of International Trade and Industry, Japan and Research Institute, King Fahd University of Petroleum and Minerals, Saudi Arabia under KFUPM/RI Project no. 21151.

\section{References}

1) Scheffer, B., de Jonge, J. C. M., Arnoldy, P., Moulijn, J. A., Bull. Soc. Chim. Belg., 93, 751 (1984).

2) Arnoldy, P., van den Heijkant, J. A. M., de Bok, G. D., Moulijn, J. A., J. Catal., 92, 35 (1985).

3) Arnoldy, P., de Booys, J. L., Scheffer, B., Moulijn, J. A., J. Catal., 96, 122 (1985).

4) Scheffer, B., Dekker, N. J. J., Mangnus, P. J., Moulijn, J. A., J. Catal., 121, 31 (1990).

5) Inamura, K., Takyu, T., Okamoto, Y., Nagata, K., Inamura, T., J. Catal., 133, 498 (1992).

6) Seshaduri, K. S., Massoth, F. E., Petrakis, L., J. Catal., 19, 95 (1970).

7) Lojacono, M., Verbeek, J. L., Schuit, G. C. A., J. Catal., 29, 463 (1973).

8) Konings, A. J. A., Brentjens, W. L. J., Koningsberger, D. C., de Beer, V. H. J., J. Catal., 67, 145 (1981).

9) Konings, A. J. A., Valester, A., de Beer, V. H. J., Prince, R., J. Catal., 76, 466 (1982).

10) Derouane, E. G., Pedersen, E., Clausen, B., Gabelica, Z., Topsøe, H., J. Catal., 107, 587 (1987).

11) Kim, S., Woo, S. I., J. Catal., 74, 109 (1991).

12) Derouane, E. G., Pedersen, E., Clausen, B. S., Gabelica, Z., Candia, R., Topsøe, H., J. Catal., 99, 253 (1986).

13) Bhaduri, M., Hernandez, J., Thomas, W. J., Appl. Catal., 8, 85 (1983).

14) Muijsers, J. C., Weber, Th., van Hardeveld, R. M., Zandbergen, H. W., Niemantsverdrite, J. W., J. Catal., 157, 698 (1995).

15) Gautherin, J. C., Le Boete, F., Colson, J. C., J. Chim. Phys., 71, 771 (1974)

16) Zabala, J. M., Grange, P., Delmon, B., C. R. Acad. Sci. Ser., C279, 725 (1974).

17) Grange, P., Catal. Rev., 21, 135 (1980).

18) Keith, W., Lojacono, M., "The Surface Chemistry of Molybdena Alumina Catalysts," presented to the VIth International Congress on Catalysis, London, July, 1976, paper A-16.

19) Abdo, S., Clarkson, R. B., Hall, W. K., J. Phys. Chem., 80, 2431 (1976).

20) Abdo, S., Kazusaka, A., Howe, R. F., J. Phys. Chem., 85, 1380 (1981). 
要 旨

\section{昇温硫化-ESR 併用法（TPS-ESR 法）を用いた $\mathrm{CoMo}^{-} \mathrm{Al}_{2} \mathrm{O}_{3}$ 触媒のキャラクタリゼーション}

林 英治 ${ }^{\dagger 1)}$ ，岩松栄治 ${ }^{\dagger 1)}$, Shakeel AHMED ${ }^{\dagger 1)}$, Augustin K.K. LEE ${ }^{\dagger 1)}$, Halim HAMID ${ }^{\dagger 1)}$ ，真田雄三 ${ }^{\dagger 11}$ ，米田俊一 ${ }^{\dagger 2}$

†1) Research Institute, King Fahd University of Petroleum and Minerals, Dhahran 31261, Saudi Arabia

†2) (財)石油産業活性化センター石油基盤技術研究所高機能触媒研究室, 213-0012 川崎市高津区坂戸 3-2-1 神奈川サイエンスパー クビル（KSP） R\&D 棟 D12F-1237

昇温硫化法（Temperature-Programmed Sulfiding; TPS）と電子 スピン共鳴法（ESR）を併用することにより, $\mathrm{CoMo}^{-} \mathrm{Al}_{2} \mathrm{O}_{3}$ 触 媒のキャラクタリゼーションを行った。 $\mathrm{Al}_{2} \mathrm{O}_{3}$ 上に担持された $\mathrm{MoO}_{3}$ の昇温硫化挙動を等温および昇温硫化過程における $\mathrm{Mo}^{5+}$ $\mathrm{ESR}$ ピーク強度と比較した。アルミナ上に担持された $\mathrm{MoO}_{3}$
の $\mathrm{Mo}^{6+}$ は，極めて温和な条件下で $\mathrm{H}_{2} \mathrm{~S}+\mathrm{H}_{2}$ 混合ガスにより還 元され $\mathrm{Mo}^{5+}$ となり，さらにこの $\mathrm{Mo}^{5+} \mathrm{ESR}$ ピークは $200^{\circ} \mathrm{C}$ 付 近で $\mathrm{H}_{2} \mathrm{~S}$ の放出， $\mathrm{H}_{2}$ の消費を伴い急激に低下する。ESR で観 測される $\mathrm{Mo}^{5+}$ 種が硫黄原子と結合しているものと考えられ る。

\section{Keywords}

Cobalt molybdena alumina, Characterization, Sulfiding mechanism, ESR, Temperature-programmed sulfiding, Catalyst 